Marcin Maciołek ${ }^{* *}$

Uniwersytet Śląski $w$ Katowicach

(D) https://orcid.org/0000-0002-9147-1283

\title{
Sprawozdanie z konferencji naukowej „Tradycja w języku - język w tradycji" \\ (Katowice, 14 maja 2018)
}

\author{
A Report from the Academic Conference \\ "Tradition in Language - Language in Tradition" \\ (Katowice, 14 May 2018)
}

Dnia 14 maja 2018 roku w sali Rady Wydziału Filologicznego odbyła się ogólnopolska konferencja naukowa „Tradycja $w$ języku - język $w$ tradycji” zorganizowana przez Instytut Języka Polskiego im. Ireny Bajerowej Uniwersytetu Śląskiego w Katowicach oraz Katedrę Międzynarodowych Studiów Polskich tejże Uczelni. Było to czwarte spotkanie z cyklu „Język - historia i współczesność". W konferencji wzięli udział przedstawiciele ośmiu ośrodków akademickich w Polsce: pracownicy naukowi i doktoranci Uniwersytetu Śląskiego w Katowicach, Uniwersytetu Warszawskiego, Uniwersytetu Wrocławskiego, Uniwersytetu im. Adama Mickiewicza w Poznaniu, Uniwersytetu Łódzkiego, Uniwersytetu Jana Kochanowskiego w Kielcach, Uniwersytetu Mikołaja Kopernika w Toruniu oraz Akademii im. Jana Długosza w Częstochowie.

Konferencję otworzyła Magdalena Pastuch, prodziekan Wydziału Filologicznego ds. promocji i współpracy z otoczeniem. Uczestników przywitali Mirosława Siuciak, dyrektor Instytutu Języka Polskiego im. Ireny Bajerowej, oraz Romuald Cudak, kierownik Katedry Międzynarodowych Studiów Polskich.

Obrady rozpoczęły się od sesji plenarnej, prowadzonej przez Mirosławę Siuciak z Instytutu Języka Polskiego im. Ireny Bajerowej. Audytorium wysłuchało w tej części czterech wystąpień. Jako pierwsze zaprezentowały się Beata Duda, Joanna Przyklenk i Katarzyna Sujkowska-Sobisz z Uniwersytetu Śląskiego w Katowicach. Prelegentki, zainteresowane rozwojem lingwistyki cyfrowej, podjęły rozważania nad statusem tej dyscypliny w kontekście tradycji badań językoznawczych. Swoją uwagę poświęciły również problemom definicyjnym lingwistyki - oraz szerzej: humanistyki - cyfrowej. W kolejnym wystąpieniu Izabela Ejsmunt-Wieczorek z Uniwersytetu Łódzkiego omówiła kwestię polisemii w gwarach. Referentka zwróciła uwagę na to, że choć zagadnienie jednostek wieloznacznych było niejednokrotnie rozpatrywane przez badaczy, to problem wyrazów polisemantycznych $w$ gwarach nie został dotychczas zanalizowany w wystarczającym stopniu. Przedstawiła również propozycje rozwiązania trudności metodologicznych $w$ tym zakresie. Przedostatni referat

\footnotetext{
* e-mail: karolina.lisczyk@wp.pl

** e-mail: marcin.maciolek@wp.pl
} 
w tej części obrad wygłosiły Magdalena Derwojedowa i Monika Kwiecień z Uniwersytetu Warszawskiego. Prelegentki dowodnie wykazały, że wyrazy określane mianem nowych często charakteryzują się długą tradycją językową. Dość powszechnie stosowane kryterium nowości jest bowiem niepewne, a pozornie nowe wyrazy są jedynie powtórnie odkrywane. Sesję plenarną zakończyło wystąpienie Grzegorza Zarzecznego z Uniwersytetu Wrocławskiego. Referent analizował na wybranym przykładzie językowe cechy pism urzędowych. Wskazał również przyczyny, dla których styl urzędowy dokumentów utrudnia, a nawet uniemożliwia właściwe odczytanie treści przez odbiorcę. Obrady plenarne, podobnie jak kolejne części konferencji, zwieńczyła dyskusja i pytania do poszczególnych badaczy.

Pierwszą sekcję, prowadzoną przez Karolinę Lisczyk z Instytutu Języka Polskiego im. Ireny Bajerowej, otworzyły swoim referatem Renata Bizior i Dorota Suska z Akademii im. Jana Długosza w Częstochowie. Prelegentki przedmiotem zainteresowania uczyniły gazetki rękopiśmienne Jędrzeja Kitowicza, omawiając ich status komunikacyjny i genologiczny. Scharakteryzowały także strategie tekstowe służące budowaniu wiarygodności przekazu, odnosząc omawiane zagadnienia do sytuacji komunikacyjno-informacyjnej panującej za czasów Kitowicza. Jako druga wystąpiła Katarzyna Sornat z Uniwersytetu Warszawskiego. Słuchacze mieli okazję poznać wyniki analiz leksykalno-semantycznych, którym poddała 480 trwałych połączeń wyrazowych wyekscerpowanych z wybranych utworów Wacława Potockiego. Na ich podstawie referentka wskazywała cechy obyczajowości sarmackiej, jednocześnie podkreślając żywotność badanych jednostek we współczesnej polszczyźnie. Rozważania historycznojęzykowe podjęła w swoim wystąpieniu również następna prelegentka - Dorota Połowniak-Wawrzonek z Uniwersytetu Jana Kochanowskiego w Kielcach. Badaczka zajęła się zagadnieniem wpływu twórczości Aleksandra Fredry na kształt frazeologizmów i przysłów obecnych we współczesnej polszczyźnie. Wskazała liczne warianty stałych połączeń słownych, które w zmodyfikowanej postaci przetrwały w języku do dziś. Ostatni referat $w$ sekcji, wygłoszony przez Rafała Biskupa z Uniwersytetu Wrocławskiego, dotyczył śląskich tłumaczeń dzieł Friedricha Schillera z przełomu XIX i XX wieku. Prelegent nie tylko ukazał specyfikę językową tych przekładów, ale też próbował odpowiedzieć na pytanie: Dlaczego dzieła Schillera były tłumaczone na regiolekt śląski?

W drugiej sekcji, prowadzonej przez Marcina Maciołka z Katedry Międzynarodowych Studiów Polskich UŚ, również wygłoszono cztery referaty. Jako pierwsi zaprezentowali się Magdalena Bator z Akademii im. Jana Długosza w Częstochowie oraz Radosław Dylewski z Uniwersytetu im. Adama Mickiewicza w Poznaniu. W swoim wystąpieniu przedstawili wyniki analizy najnowszych zapożyczeń z języka angielskiego, wyekscerpowanych z internetowych forów dyskusyjnych, zarówno o tematyce ogólnej, jak i sprofilowanych tematycznie (tj. dotyczących np. gier komputerowych, subkultur młodzieżowych czy określonych dyscyplin sportowych). Zgromadzony materiał leksykalny (zebrany korpus obejmował ponad 1000 jednostek) uporządkowali, biorąc pod uwagę przedmiot zapożyczania oraz stopień asymilacji wyrazów angielskich w polszczyźnie. Dzięki prezentacji słuchacze mogli jednocześnie poznać anglicyzmy, których używają obecnie najmłodsze pokolenia Polaków. Kolejna prelegentka, Anna Stefan z Uniwersytetu tódzkiego, podzieliła się ze słuchaczami swoimi spostrzeżeniami na temat wybranych tendencji rozwojowych zaznaczających się coraz wyraźniej w morfoskładni języka polskiego i słoweńskiego. Badaczka szczególną uwagę zwróciła na proces wkraczania form dopełniacza rzeczowników nieżywotnych do 
biernika w języku polskim (por. wysłać e-maila zamiast tradycyjnego wysłać e-mail) oraz zjawisko niejako odwrotne $w$ języku słoweńskim, polegające na zastępowaniu dopełniacza biernikiem w zdaniach zaprzeczonych. Następnie referat wygłosiła Katarzyna Wyrwas z Uniwersytetu Śląskiego w Katowicach, która omówiła najstarsze słownictwo budowlane w polszczyźnie. Rozwój leksyki sytuującej się we wskazanym obszarze (polu) tematycznym, a wyekscerpowanej głównie ze Słownika staropolskiego, przedstawiła referentka na szerokim tle kulturowym. Jako ostatni w tej sekcji wystąpił Kacper Kardas z Uniwersytetu Mikołaja Kopernika w Toruniu. Wziął on pod językoznawczą lupę kluczowy dla relacjonowanej konferencji leksem tradycja. Prelegent omówił okoliczności pojawienia się wskazanej jednostki $w$ polszczyźnie oraz niezwykle skrupulatnie przedstawił etymologię łacińskiego traditio, od którego polski rzeczownik tradycja bierze swój początek.

Konferencję zamknęły obrady plenarne, prowadzone przez pomysłodawców i organizatorów konferencji - Karolinę Lisczyk i Marcina Maciołka. Ta część rozpoczęła się od wystąpienia Wojciecha Hofmańskiego z Uniwersytetu im. Adama Mickiewicza w Poznaniu. Autor referatu postanowił przyjrzeć się uważniej leksykalno-komunikacyjnym aspektom zjawiska interkomprehensji, rozpatrując je $w$ kontekście słowiańskiej przestrzeni etnokulturowej. Oglądu wskazanego fenomenu badacz dokonał głównie z punktu widzenia glottodydaktyki polonistycznej. Dwa kolejne referaty zostały wygłoszone przez doktorantki Uniwersytetu Śląskiego w Katowicach. Iuliia Gunko na podstawie przeprowadzonych badań ankietowych przedstawiła językowy obraz Ukraińców i Polaków oraz jego przeobrażenia w polszczyźnie. Olena Stanisheuska natomiast zwróciła uwagę na zjawisko homonimii międzyjęzykowej, omawiając na wybranych przykładach źródła homonimii polsko-ukraińskiej.

Konferencja „Tradycja $w$ języku - język w tradycji” zgromadziła nie tylko badaczy prezentujących różnorodne problemy lingwistyczne skoncentrowane wokół zagadnień sygnalizowanych tematyką spotkania, ale także liczne audytorium zainteresowane podejmowaną problematyką. Podobnie jak $w$ poprzednich trzech edycjach, także i tym razem ożywione dyskusje towarzyszące obradom pozwalają sądzić, że wydarzenie to stanowiło istotne źródto wielu inspiracji badawczych. 